\title{
Genetically Decreased Spinal Cord Copper Concentration Prolongs Life in a Transgenic Mouse Model of Amyotrophic Lateral Sclerosis
}

\author{
Mahmoud Kiaei, ${ }^{1,3,4}$ Ashley I. Bush, ${ }^{2,7}$ Brett M. Morrison, ${ }^{3,4}$ John H. Morrison, ${ }^{3,4}$ Robert A. Cherny, ${ }^{7}$ Irene Volitakis, ${ }^{7}$ \\ M. Flint Beal, ${ }^{1}$ and Jon W. Gordon ${ }^{3,4,5,6}$ \\ ${ }^{1}$ Department of Neurology and Neuroscience, Weill Medical College of Cornell University, New York, New York 10021, ${ }^{2}$ Laboratory for Oxidation Biology, \\ Genetics and Aging Research Unit, Massachusetts General Hospital East, Charlestown, Massachusetts 02129, ${ }^{3}$ Neurobiology of Aging Laboratories and \\ ${ }^{4}$ Fishberg Research Center for Neurobiology and Departments of ${ }^{5}$ Geriatrics and Adult Development and ${ }^{6}$ Obstetrics/Gynecology and Reproductive Science, \\ Mount Sinai School of Medicine, New York, New York 10029, and ${ }^{7}$ Mental Health Research Institute of Victoria and Department of Pathology, The \\ University of Melbourne, Parkville, Victoria, 3052, Australia
}

Mutations in the $\mathrm{Cu} / \mathrm{Zn}$ superoxide dismutase (SOD1) gene cause familial amyotrophic lateral sclerosis (FALS) by gain of an aberrant function that is not yet well understood. The role of $\mathrm{Cu}^{2+}$ in mediating the toxicity of mutant SOD1 has been earnestly contested. We tested the in vivo effects of genetically induced copper deprivation on the ALS phenotype of transgenic mice expressing G86R mutant mouse SOD1, a protein that fails to incorporate $\mathrm{Cu}^{2+}$ in its active site. Genetically copper-deficient SOD1 ${ }^{\mathrm{G} 86 \mathrm{R}}$ transgenic mice were produced by mating SOD $1{ }^{\text {G86R }}$ males to female carriers of the X-linked mottled/brindled (Mobr) mutation. We found that the Mobr allele causes a severe $(\sim 60 \%)$ depletion of spinal cord copper levels; however, despite the burden of double genetic lesions, it lengthens the lives of SOD1 ${ }^{\mathrm{G} 86 \mathrm{R}}$ transgenic mice by $9 \%$. These findings provide evidence supporting a role for copper in the pathogenesis of FALS linked to SOD1 mutations.

Key words: superoxide dismutase; amyotrophic lateral sclerosis; copper; mottled/brindled; neurodegeneration; motor neuron

\section{Introduction}

The pathogenic mechanism of amyotrophic lateral sclerosis (ALS)-associated mutant $\mathrm{Cu} / \mathrm{Zn}$ superoxide dismutase (mSOD1) appears to be a biochemical gain-of-function independent of SOD activity (Reaume et al., 1996; Bruijn et al., 1998). Inappropriate release of $\mathrm{Cu}$ redox activity may play a role in the disease mechanism (Wiedau-Pazos et al., 1996; Nagano et al., 1999); however, mSOD1 species possess 0\% (e.g., H46R and G85R) to $100 \%$ (e.g., G37R) of wild-type SOD activity, suggesting that pathogenicity is not directly related to the activity of $\mathrm{Cu}$ at the active site of SOD1 (Borchelt et al., 1994). Underscoring this, a recent study (Subramaniam et al., 2002) reported that neurodegeneration in transgenic mice overexpressing mutant SOD1 was not rescued by genetic removal of the copper chaperone for SOD1 (CCS), which optimizes the insertion of $\mathrm{Cu}^{2+}$ into the buried active site. Dismutase activity was indeed partially reduced in the $\mathrm{CCS}^{-1-} /$ mutant SOD1-crossed mice compared with SOD transgenics (Subramaniam et al., 2002).

We and others have argued that these findings do not allow us

Received May 24, 2004; revised July 12, 2004; accepted Aug. 1, 2004

This work was supported in part by grants from the Amyotrophic Lateral Sclerosis Association (A.I.B., J.W.G., J.H.M.) and by National Institutes of Health Grants AG 10520 to J.W.G. and AG 12686 to A.I.B.

Correspondence should be addressed to Dr. Mahmoud Kiaei, Department of Neurology and Neuroscience, Weill Medical College of Cornell University, New York, NY 10021. E-mail: mak2026@med.cornell.edu. DOI:10.1523/JNEUROSCI.2000-04.2004

Copyright $\odot 2004$ Society for Neuroscience $\quad$ 0270-6474/04/247945-06\$15.00/0 to disqualify $\mathrm{Cu}$ from the pathogenesis of this disorder (Beckman et al., 2002; Bush, 2002; Valentine and Hart, 2003). For example, a pro-oxidative interaction between $\mathrm{Cu}$ and SOD1 outside of the active site of the protein has not yet been excluded. The pathological $\mathrm{Cu}$-dependent pro-oxidant reactions attributed to SOD1 include peroxidation (Wiedau-Pazos et al., 1996), peroxynitrite generation (Estevez et al., 1999), and inappropriate hydrogen peroxide generation (Said Ahmed et al., 2000). The pro-oxidant activities can be mediated by non-dismutase $\mathrm{Cu}$ binding sites on the protein (Bush, 2002; Valentine and Hart, 2003). Furthermore, recent studies have shown that CCS is not obligatory for the insertion of Cu into SOD1 (Carroll et al., 2004), and therefore CCS ablation is no longer expected to abolish $\mathrm{Cu}$ binding to SOD1.

We studied transgenic mice that express mutant SOD1 ${ }^{\text {G86R }}$ (Ripps et al., 1995). SOD $1^{\mathrm{G} 86 \mathrm{R}}$ fails to incorporate $\mathrm{Cu}$ into its active site in mouse tissue and in cell culture (Hayward et al., 2002). This familial ALS (FALS) model expresses a mutation of mouse SOD1 [analogous to the G85R mutation of human SOD1, which also lacks SOD activity (Borchelt et al., 1994)] and develops rapidly progressive fatal neurodegeneration between the ages of 90 and $120 \mathrm{~d}$ (Morrison et al., 1998). To induce a specific depletion of tissue $\mathrm{Cu}$, we crossed the SOD $1{ }^{\mathrm{G} 86 \mathrm{R}}$ mice with mice carrying the mottled/brindled (Mobr) mutation. This X-linked mutation inhibits the activity of an ATPase that transports $\mathrm{Cu}^{2+}$ across the intestinal lumen. The mutant allele causes severe copper deficiency that can be lethal (Hunt, 1974). Here we report 
that despite the double-mutant lesion, SOD1 ${ }^{\text {G86R }}$ transgenic progeny possessing the Mobr allele had improved survival compared with the SOD $1{ }^{\mathrm{G} 86 \mathrm{R}}$ transgenic progeny without the Mobr allele. Therefore, the beneficial effects of lowering cellular $\mathrm{Cu}$ levels in this model may be mediated by reduction of copper incorrectly incorporated into mutant SOD1.

\section{Materials and Methods}

Transgenic mice. All protocols were conducted within National Institutes of Health guidelines for animal research and were approved by the Institutional Animal Care and Use Committee. C57BL/6 females with mottled/brindled (heterozygous Mobr females, Mobr/XX) (The Jackson Laboratory, Bar Harbor, ME) were bred to C57BL/6 males to produce heterozygous Mobr females. Highly inbred transgenic male FVB/N mice overexpressing mouse SOD $1^{\text {G86R }}$ [now available from The Jackson Laboratory as Stock \#005110 FVB-Tg(Sod1-G86R)M1Jwg/J] were crossed with heterozygous Mobr females. Offspring were screened by PCR for the SOD1 ${ }^{\text {G86R }}$ transgene as published previously (Ripps et al., 1995). Screening for the Mobr mutation was performed by examination of the coat color [i.e., males and females with agouti coat color were without the Mobr gene; females expressing the diluted gray pigment characteristic of Mobr mosaicism were identified as heterozygous Mobr females, and males that were uniformly gray were identified as hemizygous Mobr males $(\mathrm{Mobr} / \mathrm{Y})]$. Litters were separated at weaning and maintained until symptoms of neurodegeneration appeared. Animals were observed daily beginning at 85-90 d of age, because our previous work had shown that the SOD1 ${ }^{\text {G86R }}$ animals without the Mobr gene develop motor weakness after $90 \mathrm{~d}$. Mice then were followed for progression of symptoms. When clinical examination of the diseased animals determined that they were unable to right themselves or take food or water, death was considered imminent and the animals were killed.

Mobr males (Mobr/Y) on C57BL/6 background are smaller, develop stiffness of the hind limbs as well as hypoactivity, and usually die 2-3 weeks after birth. We found, however, that by crossing C57BL/6 female heterozygotes for Mobr to our SOD $1{ }^{\mathrm{G} 86 \mathrm{R}}$ males in FVB/N background, the hemizygous Mobr male progeny without SOD $1{ }^{\mathrm{G} 86 \mathrm{R}}$ consistently survived for $>6$ months. We examined 10 Mobr mice (Mobr/Y) in C57BL/ 6/FVB/N (hybrid) background for 6 months. Mild tremor in their limbs and gray coat color were observed; otherwise they exhibited no major abnormal behaviors or phenotype, and all 10 survived to 6 months. The milder phenotype of the Mobr/Y males on the hybrid C57BL/6/FVB/N may be attributable to partially elevated $\mathrm{Cu}$ levels caused by the influence of FVB/N background alleles. The brain Cu levels at 2 weeks of age were $\sim 47 \%$ higher in C57BL/6/FVB/N hybrid Mobr males ( $0.995 \pm 0.233 \mu \mathrm{g} / \mathrm{gm}$ wet weight $)$ than in C57BL/6 Mobr males $(0.675 \pm 0.120 ; p<0.05)$.

The ability to produce hemizygous Mobr males that survive long enough to develop the SOD $1{ }^{\mathrm{G} 86 \mathrm{R}}$-related FALS phenotype, and the capacity to identify the presence of the Mobr gene by simple visual inspection, facilitated an evaluation of genetically induced copper deficiency on the longevity of both male and female mice carrying the SOD $1^{\mathrm{G} 86 \mathrm{R}}$ transgene.

Tissue copper measurements. Mice were deeply anesthetized with an equal mixture of ketamine $(100 \mathrm{mg} / \mathrm{ml})$ and xylazine $(20 \mathrm{mg} / \mathrm{ml})$. The animals were perfused transcardially with cold $0.1 \mathrm{M}$ PBS for $10 \mathrm{~min}$. Brains and spinal cords were removed, weighed, and freeze dried for copper measurement. Tissues were digested overnight at room temperature in $2 \mathrm{ml}$ of concentrated $\mathrm{HNO}_{3}$. Partially digested samples were then heated at $90^{\circ} \mathrm{C}$ on a heating block for $15 \mathrm{~min}$ and then allowed to cool for $10-20 \mathrm{~min}$. An equivalent volume of concentrated $\mathrm{H}_{2} \mathrm{O}_{2}$ was added, and effervescence was allowed to subside for 20-30 min. Digested samples were then heated at $90^{\circ} \mathrm{C}$ for $15 \mathrm{~min}$ and allowed to cool. The completely digested tissues were then diluted in $1 \% \mathrm{HNO}_{3}$ to a concentration approximating $0.2 \%$ total dissolved solids in acid-washed tubes. Each tissue sample was then measured by inductively coupled plasma mass spectrometry (Varian Ultramass, Melbourne, Australia) in triplicate and compared with metal standards as described previously (Cherny et al., 2001).

Histochemistry and immunocytochemistry. Mice were perfused transcardially with cold $0.1 \mathrm{M}$ PBS for $1 \mathrm{~min}$ followed by cold $4 \%$ paraformal- dehyde in PBS for $10 \mathrm{~min}$, and the spinal cords were removed rapidly, blocked coronally, and postfixed in $4 \%$ paraformaldehyde in PBS for 6 $\mathrm{hr}$. Blocks were cryoprotected in 30\% sucrose for $24 \mathrm{hr}$ and sectioned on a cryostat at $40 \mu \mathrm{m}$.

Parallel series of sections were collected for immunocytochemistry and Nissl staining (cresyl violet). Tissue sections for single-label immunocytochemistry were incubated overnight at $4^{\circ} \mathrm{C}$ in polyclonal antibody (rabbit IgG) against glial fibrillary acidic protein (GFAP) diluted to 1:50 in $0.01 \mathrm{M}$ PBS containing $0.3 \%$ Triton X-100 and $0.5 \mathrm{mg} / \mathrm{ml}$ bovine serum albumin (Biomeda, Foster City, CA). The sections were then processed by the avidin-biotin-peroxidase method with Vectastain ABC kits (Vector Laboratories, Burlingame, CA) and 3,3'-diaminobenzidine. Photomicrographs were taken on a Zeiss Axiophot II microscope.

Determination of SOD1 activity and staining. Animals were killed under anesthetic, and brains and spinal cords were dissected out and frozen on dry ice. These tissues were homogenized in $4 \mathrm{vol}$ of $0.05 \mathrm{M}$ potassium phosphate buffer, $\mathrm{pH} 7.8$, followed by brief sonication. Samples were centrifuged for $5 \mathrm{~min}$ at $20,000 \times \mathrm{g}$, and then supernatants were stored at $-80^{\circ} \mathrm{C}$. SOD activity was assayed by the modification of the method described by Beauchamp and Fridovich (1971). Briefly, xanthine/xanthine oxidase was used to produce superoxide flux. Nitroblue tetrazolium (NBT) reduction by superoxide radicals to blue formazan was measured at $560 \mathrm{~nm}$ in a PerkinElmer Life Sciences (Emeryville, CA) Lambda 40 UV/VIS spectrophotometer at room temperature. The rate of NBT reduction in the absence of tissue was used as the reference rate $(0.020 \pm$ $0.005 \mathrm{AU} / \mathrm{min}$ ). The amount of inhibition was defined as a percentage of the reference rate of NBT reduction. The reaction mixture contained 50 mM potassium phosphate, $\mathrm{pH}$ 10.2, $100 \mu \mathrm{M}$ xanthine, 1 mM EDTA, $1 \mathrm{U}$ catalase, $56 \mu \mathrm{M}$ NBT, xanthine oxidase, and tissue sample up to $200 \mu \mathrm{g}$ of protein.

For activity gel analyses, brain and spinal cord tissue homogenates (40 $\mu \mathrm{g}$ of total protein) were electrophoresed on $4-20 \%$ gradient nondenaturing polyacrylamide gel and visualized for SOD activity bands according to the modified method of Steinman (1985). Briefly, the gel was soaked in $20 \mathrm{~mm}$ potassium phosphate, $\mathrm{pH} 7.8$, containing $28 \mu \mathrm{M}$ riboflavin and $28 \mathrm{~mm}$ EDTA for $15 \mathrm{~min}$, rinsed in water, and then soaked in $2.5 \mathrm{~mm}$ NBT for $15 \mathrm{~min}$. The gel was rinsed in water and placed in a dry tray and illuminated with fluorescent light for 5-10 min to generate superoxide radicals. The band in the gel in which SOD is present is depleted of superoxide radicals, unable to reduce the NBT, leaving a white band in the blue background of the gel. Mouse and human SOD1 migrate differently through the gel and can be differentiated.

Western blot analysis. Brain and spinal cord tissue homogenates of total protein concentrations were measured by BCA assay (Pierce, Rockford, IL), and $40 \mu \mathrm{g}$ of total protein were electrophoresed on $4-20 \%$ gradient Tris-glycine polyacrylamide gel with SDS in running buffer and loading dye and electrotransferred to a polyvinylidene fluoride membrane (BioRad, Hercules, CA). After transfer, the membranes are blocked and then incubated with primary antibody in blocking buffer for 2-3 hr at room temperature. We used sheep anti-SOD1 antibody (Sigma, St. Louis, MO) or human SOD1-specific antibody (Chemicon, Temecula, CA) as primary antibodies and developed with HRP-conjugated secondary antibody. Some blots were stripped and reprobed with monoclonal antimouse $\beta$-tubulin antibody (Sigma). Protein bands were developed using a Supersignal West Pico chemiluminescence system (Pierce) with a CDPStar Chemiluminescent Detection System (Applied Biosystems, Foster City, CA).

Statistical analysis. Statistical analysis was performed using the MannWhitney and Kaplan-Meier test for survival measured in postnatal days and Student's $t$ test for copper analysis.

\section{Results}

\section{Genetic copper ablation of SOD $1{ }^{\text {G86R }}$ mice}

We introduced a specific genetic lesion that lowered spinal cord copper levels (the Menkes disease gene) by crossing heterozygous Mobr female mice (on C57BL/6 background) with SOD $1{ }^{\text {G86R }}$ males (on FVB/N background). This generated female and male SOD $1{ }^{\text {G86R }}$ mice possessing the Mobr allele (MobrG86R). Spinal 


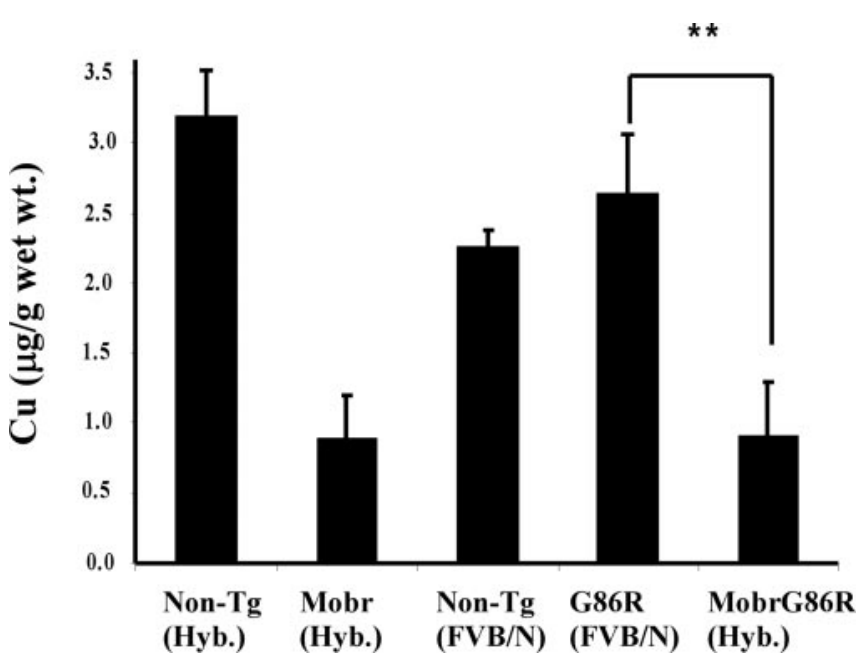

Figure 1. Effect of Mobr allele on spinal cord copper levels in SOD1 ${ }^{\mathrm{G} 66 \mathrm{R}}$ and control mice. Total copper levels in spinal cord are expressed as micrograms per gram of wet tissue. SOD ${ }^{686 \mathrm{R}}$ mice possessing the Mobr allele (heterozygote Mobr/SOD ${ }^{\text {G86R }}$ females on hybrid C57BL/6 $\times$ FVB/N background) were compared with age-matched (3 months old) SOD1 ${ }^{\text {G86R }}$ transgenic mice. SOD1 ${ }^{\mathrm{G} 86 \mathrm{R}}$ transgenic mice were on an FVB/N background, and copper levels were also compared with age-matched nontransgenic ( Non-Tg) mice on the same background, nontransgenic controls possessing the same hybrid background as the Mobr/SOD $1{ }^{\mathrm{G} 66 \mathrm{R}}$ mice, and nontransgenic mice possessing the Mobr allele on the hybrid background (hyb $=C 57 B L / 6 \times$ $\mathrm{FVB} / \mathrm{N}$ ). Values are means $\pm \mathrm{SD} ; n \geq 3$ mice; ${ }^{* *} p<0.001$.

cord copper levels in these progeny were lowered to $35 \%$ of the levels in age-matched ( 3 months old, pooled gender) SOD1 ${ }^{\text {G86R }}$ transgenic mice (Fig. 1). The marked $(p<0.001)$ lowering of tissue copper levels attributable to the Mobr genetic lesion was not caused by background effects because copper levels of SOD $1{ }^{\text {G86R }}$ transgenic mice (FVB/N background) were not significantly different when compared with either age-matched nontransgenic mice on the same background or nontransgenic controls possessing the same hybrid background as the SOD1 ${ }^{\text {G86R }}$ mice with the Mobr allele $(\mathrm{C} 57 \mathrm{BL} / 6 \times \mathrm{FVB} / \mathrm{N})($ Fig. 1).

Increased life span of Mobr/SOD1 ${ }^{\text {G86R }}$ double mutants

The cross-breeding generated SOD $1{ }^{\mathrm{G} 86 \mathrm{R}}$ mice with and without the Mobr allele, on a hybrid $(\mathrm{C} 57 \mathrm{BL} / 6 \times \mathrm{FVB} / \mathrm{N})$ genetic background. Nineteen hemizygous Mobr males with SOD1 ${ }^{\text {G86R }}$ were generated and 17 males with SOD1 ${ }^{\text {G86R }}$ without Mobr, as well as 14 heterozygous Mobr females with SOD1 ${ }^{\text {G86R }}$ and 27 females with SOD1 ${ }^{\text {G86R }}$ without Mobr. The Mobr/SOD1 ${ }^{\text {G86R }}$ doublemutant mice analyzed in this study have the same hybrid background $(\mathrm{C} 57 \mathrm{BL} / 6 \times \mathrm{FVB} / \mathrm{N})$. When the survival data from transgenic males and females was pooled, the mean age at death was $130 \pm 11 \mathrm{~d}$ for Mobr/SOD1 ${ }^{\text {G86R }}$ double mutants $(n=34)$ but only $120 \pm 12 \mathrm{~d}(n=44)$ for SOD $1{ }^{\mathrm{G} 86 \mathrm{R}}$ single mutants $(p<$ 0.001 ) (Fig. 2). This difference represents a 9\% increase in life span for the copper-deficient double-mutant Mobr/SOD1 ${ }^{\text {G86R }}$ compared with the nondeficient single-mutant SOD1 ${ }^{\mathrm{G} 86 \mathrm{R}}$ mice. There was no significant difference for the mean ages at death between male and female transgenic mice. The double-mutant Mobr/SOD $1^{\text {G86R }}$ animals also lived to longer maxima: 17 animals (50\%) lived beyond $130 \mathrm{~d}$ to a maximum of $154 \mathrm{~d}$, compared with single-mutant SOD1 ${ }^{\text {G86R }}$ mice; only $10(23 \%)$ animals lived for 130-140 d (Fig. 2).

\section{Pathological analysis of spinal cord}

The lumbar spinal cords of the mice were examined by Nissl staining for neurons as well as by GFAP immunohistochemical

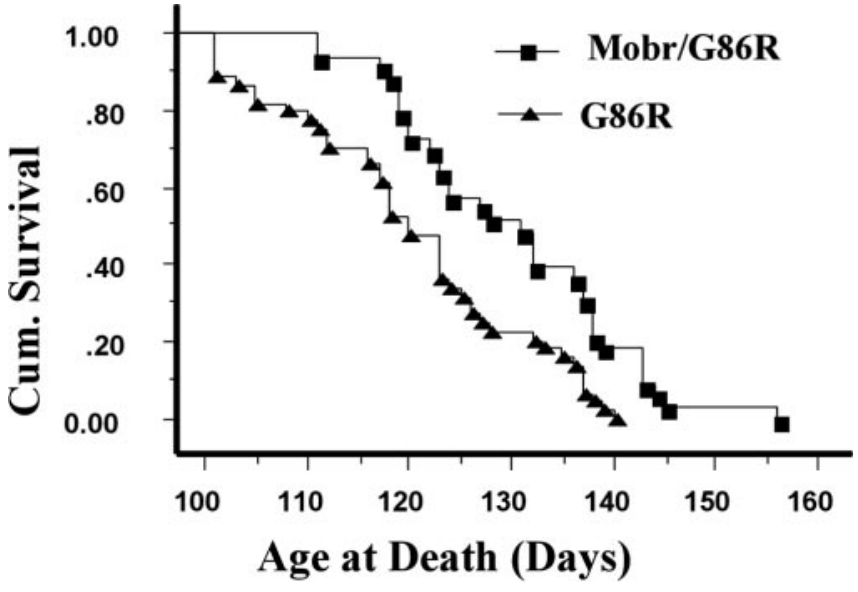

Figure 2. The effect of genetic copper ablation on survival in SOD $1^{\mathrm{G} 86 \mathrm{R}}$ transgenic mice. The Kaplan-Meier cumulative survival plot shows the cumulative probability of survival of Mobr/ SOD1 ${ }^{\mathrm{G} 86 \mathrm{R}}$ mice $(n=33)$, compared with SOD1 ${ }^{\mathrm{G} 66 \mathrm{R}}$ without Mobr $(n=44)$ (males and females pooled) both in the same background ( $h y b=(57 B L / 6 \times F V B / N)$. There is a significant increase in survival in genetically copper deficient Mobr/SOD $1^{\text {G86R }}$ mice ( $p=0.007$; by Mantel-Cox rank test).

staining for astrocytes. These data confirmed that the presence of the Mobr allele prolonged the lives of the SOD1 ${ }^{\mathrm{G} 86 \mathrm{R}}$ mice by inhibiting spinal cord pathology. Neuronal cell density in the ventral horn of the lumbar spinal cord enlargement in 125-d-old males hemizygous for Mobr (without SOD ${ }^{\text {G86R }}$ ) was similar to presymptomatic Mobr/SOD1 ${ }^{\text {G86R }}$ males of the same age (Fig. 3, compare $A, E$ and $D, H)$; however, symptomatic male SOD1 G86R mice of the same age exhibited a conspicuous loss of neurons in the ventral horn (Fig. $3 B, F$ ). Older Mobr/SOD ${ }^{\text {G86R }}$ male mice developed conspicuous neuronal loss after becoming symptomatic (156 d) (Fig. 3C,G).

GFAP immunoreactivity indicated a parallel astrocytosis in association with neuronal cell loss. In non-Tg Mobr mice (Fig. $3 I$ ) and presymptomatic Mobr/SOD ${ }^{\text {G86R }}$ mice (Fig. $3 L$ ), little GFAP immunoreactivity was apparent, whereas symptomatic SOD1 ${ }^{\text {G86R }}$ animals with or without the Mobr allele exhibited pronounced GFAP staining in the ventral horn (Fig. 3J, K).

\section{SOD1 levels and activity}

Western blot confirmed that SOD1 was overexpressed in the brains and spinal cords of the SOD $1{ }^{\text {G86R }}$ transgenic mice, and that despite lower copper levels, the Mobr allele has no effect on the SOD1 expression levels in these tissues (Fig. 4A). Calibrated densitometry of Western blots indicated that SOD1 levels were $84 \%$ higher in SOD1 ${ }^{\text {G86R }}$ transgenic mice compared with nontransgenic controls, and expression of SOD1 was 25\% higher in spinal cord than in brain (Fig. $4 A$ ). Because the SOD1 ${ }^{\mathrm{G} 86 \mathrm{R}} \mathrm{mu}$ tation abolishes SOD activity (Ripps et al., 1995), we confirmed that overexpression of the mutant transgene did not increase SOD1 activity in the SOD $1{ }^{\mathrm{G} 86 \mathrm{R}}$ mice using SOD activity gels (Fig. $4 B)$ and spectrophotometric assays (Fig. 4C).

\section{Discussion}

Our study confirms that systemic copper deficiency (induced on this occasion by a selective genetic lesion) significantly delays motor neuron degeneration in a mutant SOD1 transgenic mouse model of FALS.

Tissue culture studies have shown that copper chelation ameliorates the cytotoxic effects of transfected mutant SOD1 (Wiedau-Pazos et al., 1996). An increase in copper in erythro- 
cytes of the ALS patients has been reported with at least two SOD1 mutations (G37R and H46R) (Ogawa et al., 1997). These findings support the notion that SOD1 mutations linked to ALS exert their damaging effect in vivo through altered chemistry of $\mathrm{Cu}^{2+}$ bound to SOD1. It has been suggested previously that the $\mathrm{Cu}^{2+}$ could react with nitric oxide and superoxide in the cell to form highly reactive peroxynitrite (Beckman et al., 1993). Increased $\mathrm{Cu}^{2+}$-mediated peroxidase activity of mutant SOD1 in comparison with wildtype SOD1 has also been reported (M. B. Yim et al., 1996; H. S. Yim et al., 1997). $\mathrm{Cu}^{2+}$-mediated oxidation also has been proposed to be pathogenic by causing misfolding and aggregation of mutant SOD1 (Rakhit et al., 2002).

The copper deficiency brought about by the Mobr allele induced a slightly greater prolongation of life span than treatment of the same mouse model with oral administration of a copper chelating drug (D-penicillamine) (Hottinger et al., 1997). Similarly, treatment of transgenic SOD $1^{\text {G93A }}$ mice with trientine also delayed significantly the onset of neurological signs (Nagano et al., 1999), but neither intervention completely rescued the lethal phenotype. Although the $9 \%$ increase in life span induced by the Mobr allele that we observed is modest, one must consider that the $\mathrm{Cu}$ depletion genetically induced by the Mobr (Menkes disease) lesion is life threatening. Therefore, it is very surprising that animals doubly mutant for two pathogenic mutations (copper depletion plus mutant SOD1) live significantly longer than the single SOD1 mutant mice (controlled for genetic background). This means that the condition of the SOD $1^{\text {G86R }}$ mouse, which usually dies within 5 months of birth, is improved by the additional presence of severe systemic copper deficiency. This is important evidence supporting a role for copper in this disease state.

Although our results are encouraging, it is possible that tissue copper levels cannot be lowered sufficiently by this genetic lesion to prevent pathogenic interaction of tissue $\mathrm{Cu}$ with mutant SOD1. Oxidative damage could be caused by rogue catalytic reactive oxygen species production derived from a minor fraction of SOD1. The Mobr mice still have plenty of $\mathrm{Cu}$ in their tissues, and multiple and redundant pathways transport $\mathrm{Cu}$ within the cytosol. Therefore, it may be difficult to induce sufficient copper deficiency by any genetic lesion (or even by chelation therapy) to prevent some degree of $\mathrm{Cu}$ interaction with SOD1 without totally ablating tissue $\mathrm{Cu}$, which is not a viable strategy. Therefore, potential drug therapy would need to specifically target $\mathrm{Cu}$ interaction in mutant SOD1 rather than induce total tissue $\mathrm{Cu}$ depletion.

An interesting feature of our findings is that mean survival is extended, but the death rate, once symptoms appear, is unaltered. A similar finding was made when B-cell lymphoma/leukemia-2 transgenes were overexpressed in a mouse model of FALS (Kostic et al., 1997). This suggests that the natural history of the disease
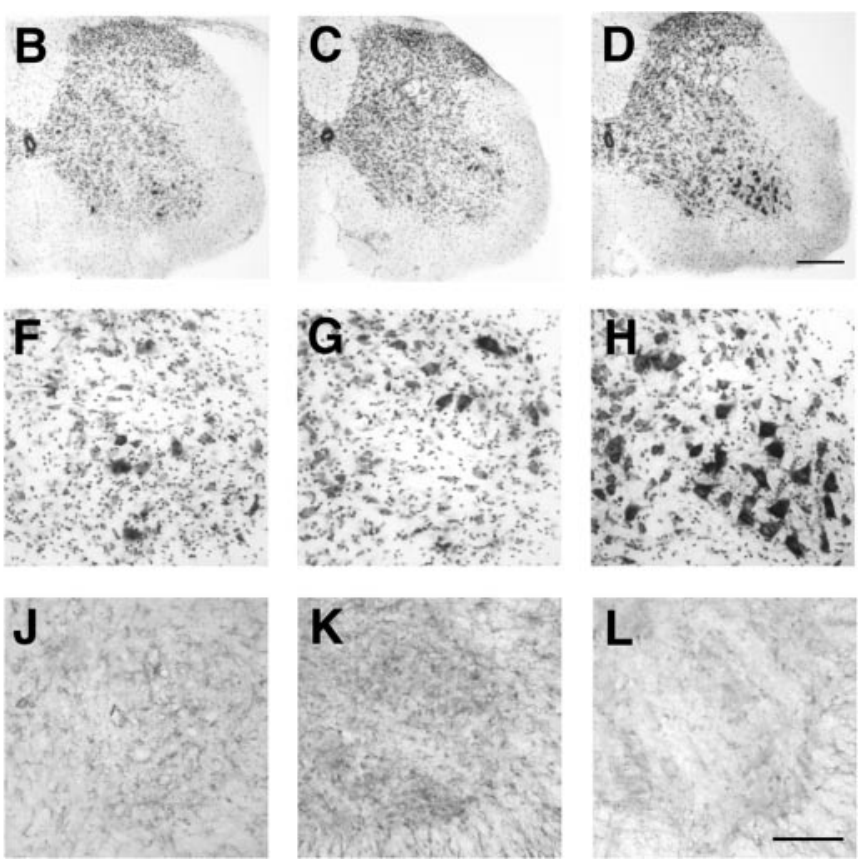

Figure 3. Spinal cord glial and neuronal staining of SOD $1^{\text {G86R }}$ and Mobr/SOD1 ${ }^{\text {G86R }}$ mice. Nissl-stained sections and GFAP immunoreactivity from lumbar spinal cord enlargements of 125-d-old nontransgenic hemizygous Mobr males $(A, E, I)$, fully presed. Although the dorsal and intermediate zones of the spinal cord are normal in all animals, a reduction in neuronal density

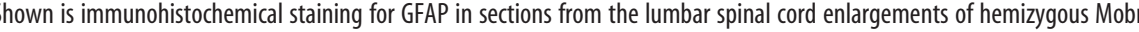
SOD1 ${ }^{\text {G86R }}$ males with Mobr $(K)$, as compared with asymptomatic Mobr males ( $/$ ) or presymptomatic SOD1 ${ }^{\text {G86R }}$ males with Mobr (L). Scale bars: $A-D, 200 \mu \mathrm{m} ; E-L, 100 \mu \mathrm{m}$.

may have two distinct phases: a prodromal phase during which the biochemical lesion (e.g., SOD1 aggregation, mitochondrial damage) accumulates to a critical concentration threshold, followed by a propagation phase during which neuronal demise and the lethal phenotype occur. In this case, the biochemical forces that induce SOD1 aggregation might not be the same as those that then propagate tissue damage. Cu depletion may inhibit the onset of the disease, perhaps by decreasing the rate of oxidationmediated SOD1 aggregate formation (Rakhit et al., 2002); however, Cu may not necessarily contribute to the damage induced by the aggregates themselves, once they are formed.

Subramaniam et al. (2002) reported that genetic ablation of CCS did not significantly rescue the ALS phenotype in mutant SOD1 transgenic animals (G93A, G85R, and G37R). CCS promotes the insertion of $\mathrm{Cu}^{2+}$ into the active site of SOD1, and these findings were widely taken to imply that $\mathrm{Cu}^{2+}$ could be excluded from the pathophysiology of the FALS phenotype in this model. The data of Subramaniam et al. (2002), however, did not establish a decrease in Cu/SOD1 stoichiometry in $\mathrm{CCS}^{-1-}$ mice, but only a decrease in Cu-mediated SOD activity. The authors observed a decrease in ${ }^{64} \mathrm{Cu}$-radiolabeled SOD 1 in $\mathrm{CCS}^{-1-}$ mice, but this is not evidence that the stoichiometry of total $\mathrm{Cu}$ binding to SOD1 was diminished. The only tissue protein identified to incorporate ${ }^{64} \mathrm{Cu}$ after in vivo injection was SOD1, which is unusual because several proteins should have incorporated the 
A

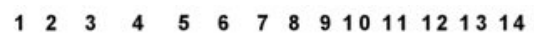

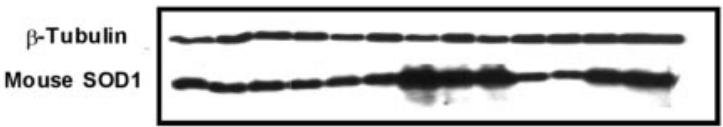

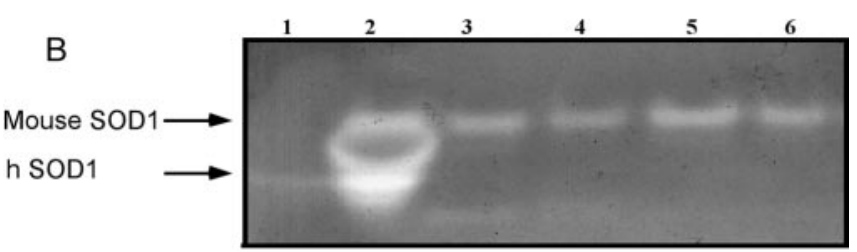

C

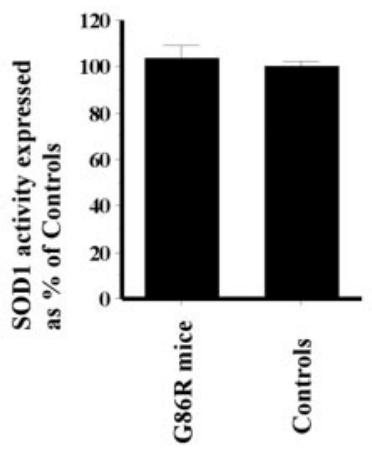

Figure 4. SOD1 levels and activity in SOD ${ }^{\mathrm{G} 66 \mathrm{R}}$ transgenic mice and controls. A, Western blot analysis of mouse SOD1 expression. Total protein from brain and spinal cord tissue homogenate (40 $\mu \mathrm{g}$ per well) was analyzed by Western blot. $\beta$-Tubulin is used as a control for loading. Samples are hybrid control spinal cord (1), brain (2), Mobr/ $Y$ spinal cords $(3,5)$, brains $(4,6)$, SOD1 ${ }^{\mathrm{G} 66 \mathrm{R}}$ spinal cords $(7,9)$, brains $(8,12,13,14), \mathrm{FVB} / \mathrm{N}$ spinal cord (10), and brain (11). $B$, SOD1 activity staining gel from brain and spinal cord tissue homogenates of G86R transgenic mice and controls. Controls are purified human SOD1 $(20 \mu \mathrm{g})$ in lane 1 and tail blood $(2 \mu \mathrm{l})$ from transgenic SOD ${ }^{\text {G93A }}$ mouse in lane 2. Non- $\mathrm{Tg}$ (FVB/N) spinal cord (lane 3) and brain (lane 4) is compared with SOD ${ }^{\text {G8R }}$ spinal cord (lane 5) and brain in lane 6 ( $40 \mu \mathrm{g}$ of total protein loaded per lane). C, Spinal cord SOD1 activity in SOD ${ }^{\text {G8R }}$ transgenic mice and non- $\mathrm{Tg}$ (FVB/N) controls measured by spectrophotometric assay and expressed as percentage of control ( $n=6$ for each group). There was no significant difference between these groups.

label. Where did the rest of the radiolabel go? The answer is probably that the samples were homogenized in EDTA and bathocuproine, high-affinity $\mathrm{Cu}$ chelators, which would have stripped all but the highest affinity binding of ${ }^{64} \mathrm{Cu}$ from the proteins of the samples. ${ }^{64} \mathrm{Cu}$ binding to lower-affinity $\mathrm{Cu}$ binding sites on SOD1 would not have survived this procedure, and therefore no conclusion about the total stoichiometry of $\mathrm{Cu}$ binding to SOD1 can be made from these results. The marked decrease in dismutase activity that was observed in the $\mathrm{CCS}^{-1-}$ / mutant SOD1 mice does not indicate that total $\mathrm{Cu}$ binding to SOD1 is decreased, because this activity is only a reflection of $\mathrm{Cu}$ binding at the high-affinity, active site; the dismutase activity assay does not reflect $\mathrm{Cu}$ bound to other sites on SOD1.

Indeed, Goto et al. (2000) have reported that in the absence of CCS, copper binds abnormally to SOD1, which increases the possibility that it would foster abnormal redox activity.

A recent publication demonstrated a mechanism responsible for CCS-independent activation of mammalian SOD1 that could bind $\mathrm{Cu}^{2+}$ using reduced glutathione in both yeast and murine cells null for CCS. (Carroll et al., 2004). SOD1 has also been identified in mitochondria inner membranous space (Higgins et al., 2002; Mattiazzi et al., 2002). How mitochondrial SOD1 obtains copper and zinc is not clear, because SOD1 has no sequence tag for importation into mitochondria and would need to be unfolded before it could cross the mitochondrial lipid bilayer.
Because abnormalities in mitochondrial morphology and function occur as a prelude to motor neuron death (Kong and $\mathrm{Xu}$, 1998), it is possible that SOD1 within the mitochondria may be critical to the pathogenesis of ALS. Together, our findings indicate that $\mathrm{Cu}^{2+}$ interaction with mutant SOD1 still appears to play an important role in the etiopathogenesis of FALS.

\section{References}

Beauchamp C, Fridovich I (1971) Superoxide dismutase: improved assays and an assay applicable to acrylamide gels. Anal Biochem 44:276-287.

Beckman JS, Carson M, Smith CD, Koppenol WH (1993) ALS, SOD and peroxynitrite. Nature 364:584.

Beckman JS, Estevez AG, Barbeito L, Crow JP (2002) CCS knockout mice establish an alternative source of copper for SOD in ALS. Free Radic Biol Med 33:1433-1435.

Borchelt DR, Lee MK, Slunt HS, Guarnieri M, Xu ZS, Wong PC, Brown Jr RH, Price DL, Sisodia SS, Cleveland DW (1994) Superoxide dismutase 1 with mutations linked to familial amyotrophic lateral sclerosis possesses significant activity. Proc Natl Acad Sci USA 91:8292-8296.

Bruijn LI, Houseweart MK, Kato S, Anderson KL, Anderson SD, Ohama E, Reaume AG, Scott RW, Cleveland DW (1998) Aggregation and motor neuron toxicity of an ALS-linked SOD1 mutant independent from wildtype SOD1. Science 281:1851-1854.

Bush AI (2002) Is ALS caused by an altered oxidative activity of mutant superoxide dismutase? Nat Neurosci 5:919-920.

Carroll MC, Girouard JB, Ulloa JL, Subramaniam JR, Wong PC, Valentine JS, Culotta VC (2004) Mechanisms for activating Cu- and Zn-containing superoxide dismutase in the absence of the CCS Cu chaperone. Proc Natl Acad Sci USA 101:5964-5969.

Cherny RA, Atwood CS, Xilinas ME, Gray DN, Jones WD, McLean CA, Barnham KJ, Volitakis I, Fraser FW, Kim Y, Huang X, Goldstein LE, Moir RD, Lim JT, Beyreuther K, Zheng H, Tanzi RE, Masters CL, Bush AI (2001) Treatment with a copper-zinc chelator markedly and rapidly inhibits beta-amyloid accumulation in Alzheimer's disease transgenic mice. Neuron 30:665-676.

Estevez AG, Crow JP, Sampson JB, Reiter C, Zhuang Y, Richardson GJ, Tarpey MM, Barbeito L, Beckman JS (1999) Induction of nitric oxidedependent apoptosis in motor neurons by zinc-deficient superoxide dismutase. Science 286:2498-2500.

Goto JJ, Zhu H, Sanchez RJ, Nersissian A, Gralla EB, Valentine JS, Cabelli DE (2000) Loss of in vitro metal ion binding specificity in mutant copperzinc superoxide dismutases associated with familial amyotrophic lateral sclerosis. J Biol Chem 275:1007-1014.

Hayward LJ, Rodriguez JA, Kim JW, Tiwari A, Goto JJ, Cabelli DE, Valentine JS, Brown Jr RH (2002) Decreased metallation and activity in subsets of mutant superoxide dismutases associated with familial amyotrophic lateral sclerosis. J Biol Chem 277:15923-15931.

Higgins CM, Jung C, Ding H, Xu Z (2002) Mutant Cu, Zn superoxide dismutase that causes motoneuron degeneration is present in mitochondria in the CNS. J Neurosci 22:RC215(1-6).

Hottinger AF, Fine EG, Gurney ME, Zurn AD, Aebischer P (1997) The copper chelator D-penicillamine delays onset of disease and extends survival in a transgenic mouse model of familial amyotrophic lateral sclerosis. Eur J Neurosci 9:1548-1551.

Hunt DM (1974) Primary defect in copper transport underlies mottled mutants in the mouse. Nature 249:852-854.

Kong J, Xu Z (1998) Massive mitochondrial degeneration in motor neurons triggers the onset of amyotrophic lateral sclerosis in mice expressing a mutant SOD1. J Neurosci 18:3241-3250.

Kostic V, Jackson-Lewis V, de Bilbao F, Dubois-Dauphin M, Przedborski S (1997) Bcl-2: prolonging life in a transgenic mouse model of familial amyotrophic lateral sclerosis. Science 277:559-562.

Mattiazzi M, D’Aurelio M, Gajewski CD, Martushova K, Kiaei M, Beal MF, Manfredi G (2002) Mutated human SOD1 causes dysfunction of oxidative phosphorylation in mitochondria of transgenic mice. J Biol Chem 277:29626-29633.

Morrison BM, Janssen WG, Gordon JW, Morrison JH (1998) Time course of neuropathology in the spinal cord of G86R superoxide dismutase transgenic mice. J Comp Neurol 391:64-77.

Nagano S, Ogawa Y, Yanagihara T, Sakoda S (1999) Benefit of a combined treatment with trientine and ascorbate in familial amyotrophic lateral sclerosis model mice. Neurosci Lett 265:159-162. 
Ogawa Y, Kosaka H, Nakanishi T, Shimizu A, Ohoi N, Shouji H, Yanagihara T, Sakoda S (1997) Stability of mutant superoxide dismutase-1 associated with familial amyotrophic lateral sclerosis determines the manner of copper release and induction of thioredoxin in erythrocytes. Biochem Biophys Res Commun 241:251-257.

Rakhit R, Cunningham P, Furtos-Matei A, Dahan S, Qi XF, Crow JP, Cashman NR, Kondejewski LH, Chakrabartty A (2002) Oxidation-induced misfolding and aggregation of superoxide dismutase and its implications for amyotrophic lateral sclerosis. J Biol Chem 277:47551-47556.

Reaume AG, Elliott JL, Hoffman EK, Kowall NW, Ferrante RJ, Siwek DF, Wilcox HM, Flood DG, Beal MF, Brown Jr RH, Scott RW, Snider WD (1996) Motor neurons in $\mathrm{Cu} / \mathrm{Zn}$ superoxide dismutase-deficient mice develop normally but exhibit enhanced cell death after axonal injury. Nat Genet 13:43-47.

Ripps M, Huntley GW, Hof PR, Morrison JH, Gordon JW (1995) Transgenic mice expressing an altered murine superoxide dismutase gene provide an animal model of amyotrophic lateral sclerosis. Proc Natl Acad Sci USA 92:689-693.

Said Ahmed M, Hung WY, Zu JS, Hockberger P, Siddique T (2000) Increased reactive oxygen species in familial amyotrophic lateral sclerosis with mutations in SOD1. J Neurol Sci 176:88-94.
Steinman HM (1985) Bacteriocuprein superoxide dismutases in pseudomonads. J Bacteriol 162:1255-1260.

Subramaniam JR, Lyons WE, Liu J, Bartnikas TB, Rothstein J, Price DL, Cleveland DW, Gitlin JD, Wong PC (2002) Mutant SOD1 causes motor neuron disease independent of copper chaperone-mediated copper loading. Nat Neurosci 5:301-307.

Valentine JS, Hart PJ (2003) Misfolded CuZnSOD and amyotrophic lateral sclerosis. Proc Natl Acad Sci USA 100:3617-3622.

Wiedau-Pazos M, Goto JJ, Rabizadeh S, Gralla EB, Roe JA, Lee MK, Valentine JS, Bredesen DE (1996) Altered reactivity of superoxide dismutase in familial amyotrophic lateral sclerosis. Science 271:515-518.

Yim HS, Kang JH, Chock PB, Stadtman ER, Yim MB (1997) A familial amyotrophic lateral sclerosis-associated $\mathrm{A} 4 \mathrm{~V} \mathrm{Cu}, \mathrm{Zn}$-superoxide dismutase mutant has a lower $\mathrm{Km}$ for hydrogen peroxide. Correlation between clinical severity and the Km value. J Biol Chem 272:8861-8863.

Yim MB, Kang J-H, Yim H-S, Kwak H-S, Chock PB, Stadtman ER (1996) A gain of function of an amyotrophic lateral sclerosis-associated $\mathrm{Cu}, \mathrm{Zn}$ superoxide dismutase mutant: an enhancement of free radical formation due to a decrease in Km for hydrogen peroxide. Proc Natl Acad Sci USA 93:5709-5714. 